\title{
Yousef Moradi. "Epigraphical and Iconographical Analysis of a Parthian Bas-Relief from Javanroud, Western Iran"
}

\section{Enrico Foietta}

\section{(2) OpenEdition Journals}

Electronic version

URL: https://journals.openedition.org/abstractairanica/53189

DOI: 10.4000/abstractairanica.53189

ISSN: 1961-960X

Publisher:

CNRS (UMR 7528 Mondes iraniens et indiens), Éditions de l'IFRI

\section{Electronic reference}

Enrico Foietta, "Yousef Moradi. "Epigraphical and Iconographical Analysis of a Parthian Bas-Relief from Javanroud, Western Iran"', Abstracta Iranica [Online], Volume 42-43| 2021, document 38, Online since 30 December 2021, connection on 16 December 2022. URL: http://journals.openedition.org/ abstractairanica/53189; DOI: https://doi.org/10.4000/abstractairanica.53189

This text was automatically generated on 16 December 2022.

All rights reserved 


\title{
Yousef Moradi. "Epigraphical and Iconographical Analysis of a Parthian Bas-Relief from Javanroud, Western Iran"
}

\author{
Enrico Foietta
}

\section{REFERENCES}

Yousef Moradi. "Epigraphical and Iconographical Analysis of a Parthian Bas-Relief from Javanroud, Western Iran”, Parthica 21, 2019, p. 143-158.

1 An interesting bas-relief from an unknown archaeological context is presented in this paper published on the journal Parthica. The small relief was found by a local dweller near Javanroud, province of Kermanshah, and there is no information recorded on its original provenance. Three standing figures performing a ceremony close to an altar are carved on its multifaceted surface. Although in some parts very much abraded, the clothes are clearly of Parthian style due to their typical form and decoration. The author correctly focuses on the frontality of the figures and clothing to suggest a dating to the Parthian period, more precisely between the 1st century BCE and the 2nd century CE.

2 Moradi's comparisons for the iconographic elements are numerous and consistent and range throughout the Near and Middle East of the Hellenistic and Parthian periods (Palmyra, Hatra, Dura-Europos, Assur, Bisoutun, Bard-e Nechandeh, Masjid-e Sulaiman, Tang-e Sarvak, etc.)

3 The proposed identification of a priest on the right side of the relief, a god in the centre (because of the fillet ties, the spear and the nymbus) and perhaps a local ruler or 'King' on the left, is striking and well supported. 
4 The final section of the article deals with the two inscriptions engraved on the left and right upper edges of the relief.

\section{AUTHORS}

\section{ENRICO FOIETTA}

University of Torino (UNITO) 